University of Nebraska - Lincoln

DigitalCommons@University of Nebraska - Lincoln

USDA National Wildlife Research Center - Staff Publications
U.S. Department of Agriculture: Animal and Plant Health Inspection Service

January 2006

\title{
Effects of addition of a bird repellent to fish diets on their growth and bioaccumulation
}

Sheenan Harpaz

Department of Aquaculture, Agricultural Research Organization, The Volcani Center, Bet Dagan, Israel, harpaz@agri.gov.il

Larry Clark

USDA/APHIS/WS National Wildlife Research Center, larry.clark@aphis.usda.gov

Follow this and additional works at: https://digitalcommons.unl.edu/icwdm_usdanwrc

Part of the Environmental Sciences Commons

Harpaz, Sheenan and Clark, Larry, "Effects of addition of a bird repellent to fish diets on their growth and bioaccumulation" (2006). USDA National Wildlife Research Center - Staff Publications. 1.

https://digitalcommons.unl.edu/icwdm_usdanwrc/1

This Article is brought to you for free and open access by the U.S. Department of Agriculture: Animal and Plant Health Inspection Service at DigitalCommons@University of Nebraska - Lincoln. It has been accepted for inclusion in USDA National Wildlife Research Center - Staff Publications by an authorized administrator of DigitalCommons@University of Nebraska - Lincoln. 


\title{
Effects of addition of a bird repellent to fish diets on their growth and bioaccumulation
}

\author{
Sheenan Harpaz ${ }^{1}$ \& Larry Clark ${ }^{2}$ \\ ${ }^{1}$ Department of Aquaculture, Agricultural Research Organization, The Volcani Center, Bet Dagan, Israel \\ ${ }^{2}$ US Department of Agriculture, Animal Plant Health Inspection Service, Wildlife Services, National Wildlife Research Center, \\ Fort Collins, CO, USA
}

Correspondence: S Harpaz, Department of Aquaculture, Agricultural Research Organization, The Volcani Center, PO Box 6, Bet Dagan 50250, Israel. E-mail: harpaz@ agri.gov.il

\begin{abstract}
The effects of adding the nonlethal bird repellent methyl anthranilate (MA), at levels of 100 and $1000 \mathrm{mg} \mathrm{kg}^{-1}$, to fish feed on the bioaccumulation and growth of juvenile $(10 \mathrm{~g})$ hybrid striped bass (Morone chrysops $\times$ M. saxatilis) and juvenile (1g) African cichlid fish Aulonocara jacobfreibergi were investigated under laboratory conditions. The bird repellent did not have any effect on the fish growth or survival over a period of 6 weeks. MA residues at low levels of $11.2 \pm 2.6 \mu \mathrm{gg}^{-1}$ were found in lipophilic tissues (liver) of MA-fed fish. Control fish, which had no MA added to their diet, had a much lower level of $0.6 \pm 0.3 \mu \mathrm{g} \mathrm{g}^{-1} \mathrm{MA}$ in their liver. Fish muscle was found to contain negligible MA residues, while the outer body surface mucus did not contain any MA. Following a 6-week depuration period, during which the previously MA-fed hybrid striped bass were fed a feed to which no MA was added, the levels of MA residues detected were reduced by one order of magnitude.
\end{abstract}

Keywords: bird repellent, methyl anthranilate, hybrid striped bass, Aulonocara jacobfreibergi

\section{Introduction}

Aquaculture ponds attract many birds, including fish-eating species (Melotti, Loro, Roncarati \& Impiccini 1994; Russell, Dare, Eaton \& Armstrong 1996). Many reports have described the damage caused to the aquaculture industry by birds (Ulenaers \& Van Vessem 1994; Fleury \& Sherry 1995; Glahn \& Brugger 1995; Glahn, Rasmussen, Tomsa \& Preusser 1999;
Glahn, Tomsa \& Preusser 1999; Belant, Tyson \& Mastrangelo 2000). Some of these studies relate specifically to the tropical fish industry (e.g. Avery, Eiselman, Young, Humphrey \& Decker 1999). Aside from direct predation on fish, many birds transmit diseases and parasites that can inflict further losses.

The estimation of economic damage caused by birds should not only refer to the direct loss of small fish at the initial stages of production in a batch culture but should also take into account the impact of early-stage potential loss on the final yield, as pointed out by Glahn, Werner, Hanson and Engle (2000). In the ornamental fish aquaculture, the losses can be extremely high because of the fact that the fish value (even at a small size) is very high and they are usually colourful, making them an easier target for fish-eating birds. Studies on captive herons carried out by Glahn, Dorr and Tobin (2000) showed that these birds at adult size required approximately $300 \mathrm{~g}$ of live catfish daily to maintain their body mass.

Besides the damage inflicted by the birds on the fish yields, some birds learn to feed on the pellets used as artificial fish feed. This has become especially problematic with the increasing use of floating pellets by the industry.

Various methods have been used by aquaculturists to discourage birds from landing in or around the ponds (Mott \& Boyd 1995). These include various types of visual deterrents, such as balloons of different shapes and colours, streamers, flags and scarecrows, firecrackers, propane cannons as well as shooting. Because of the strong controversy over the issue of shooting/killing birds (Price \& Nickum 1995; Belant et al. 2000; Blackwell, Dolbeer \& Tyson 2000) as well as the protection of nature laws, other 
nonlethal methods are recommended. A number of studies have pointed towards the advantage of using nonlethal bird repellents in order to deter birds from crops and water bodies (Clark, Shah \& Mason 1991; Dolbeer, Woronecki, Stearns \& Clark 1992; Clark \& Shah 1993; Avery 2002).

The use of methyl anthranilate (MA) has been advocated as a potent bird repellent. This chemical, a natural common secondary plant metabolite, is highly offensive to birds while mammals are either indifferent to it or even find the compound pleasant (Mason, Glahn, Dolbeer \& Reidinger 1985; Glahn, Mason \& Woods 1989). A very similar compound (dimethyl anthranilate) was successfully used as a bird repellent livestock feed additive (Mason et al. 1985; Glahn et al. 1989), although recently MA has been shown, in field tests, to act as an attractant to some beneficial insects, especially the chloropid fly Thaumatomyia glabra (James 2005).

Methyl anthranilate is used at relatively high concentrations as a grape juice flavour additive in the food industry and is listed in the USFDA generally recognized as safe (GRAS) list. The effects of MA on bird behaviour causing them to avoid coming in contact with the substance, are well documented (Mason, Adams \& Clark 1989; Clark et al. 1991; Mason, Clark \& Miller 1993). Yet, the presence of MA in the water, while acting as a bird deterrent, may also have serious effects on the aquatic organisms. It has been shown that MA, when present in the water at low concentrations $\left(20-30 \mathrm{mg} \mathrm{L}^{-1}\right)$, is acutely toxic to the fry of a number of fish species (Clark, Cummings, Bird \& Aronov 1993). Applying MA to fish feeds as well as to fish ponds, either directly to the water or by spraying the repellent around the pond area, can lead to bioaccumulation in the fish and water, possibly leading to detrimental effects on fish growth.

The purpose of the present study was to determine whether the addition of the bird repellent MA, at a level of $100 \mathrm{mg} \mathrm{kg}^{-1}$ and at a higher concentration of $1000 \mathrm{mg} \mathrm{kg}^{-1}$, to artificial fish food pellets has a detrimental effect on the growth and survival of edible and ornamental juvenile fish. In addition, the fish were also tested for bioaccumulation levels of the repellent in the various body organs of the edible fish and the entire body of the ornamental fish.

\section{Materials and methods}

Two experiments were set-up to verify the effects of MA on the growth and survival of edible and orna- mental fish. Both experiments lasted for 6 weeks. Because of the importance of bioaccumulation in edible fish, an additional follow-up experiment was conducted with the hybrid striped bass fish. In this follow-up, the fish were assayed following a depuration period in which previously MA-fed fish were given the control diet (containing no additional MA) for 6 weeks, and then they were tested for the presence of residual MA.

\section{Fish and holding facilities}

Juvenile hybrid striped bass fish (Morone chrysops $\times$ M. saxatilis), with an average weight of approximately $10 \mathrm{~g}$, were purchased from Delmarva Aquatics (Smyrna, DE, USA) and acclimatized to laboratory conditions over a period of 2 weeks.

Juvenile ornamental African cichlid fish Aulonocara jacobfreibergi, each weighing approximately $1 \mathrm{~g}$, were purchased from Schmalbach farm (Homestead, FL, USA) and were acclimatized to laboratory conditions over a period of 10 days.

At stocking and during the course of the consecutive weighing, each fish was briefly dried on a paper towel and individually weighed to the nearest $0.01 \mathrm{~g}$ using an Ohaus (Pine Brook, NJ, USA) B-300 electronic balance. Fish were matched for size, as much as possible, in order to reduce behavioural, size-related, interactions.

Hybrid striped bass were kept in round fibreglass $170 \mathrm{~L}$ tanks fitted with a drain at the centre and a flowthrough system in which the water flow rate was $2 \mathrm{~L} \mathrm{~min}^{-1}$. Each tank had a large air stone that constantly supplied aeration. A total of six tanks were used, three for the control and three for the experimental group. The water temperature fluctuated between 19 and $22{ }^{\circ} \mathrm{C}$ throughout the experimental period. A total of 22 fish were stocked in each tank. Fish were individually weighed after 3 weeks of growth, to adjust feeding level, and at the end of the 6-week growth trial when the experiment was terminated.

Cichlid fish were housed in glass aquariums, each containing $35 \mathrm{~L}$ of water and equipped with an internal biofilter through which air was bubbled at a constant rate. A total of 12 aquariums were used, six for the control-fed fish and six for the MA-treated feed. Each aquarium contained 15 fish. The temperature was maintained at $25 \pm 2{ }^{\circ} \mathrm{C}$ by heating the room in which the experiment was run. At the end of the 6week growth period, a sample of four fish was taken 
from each aquarium for total body MA residue analysis. The tank/aquarium bottoms were thoroughly cleaned once a week.

\section{Fish feeds and MA inclusion}

Fish were fed a pelleted feed (ASD2-30) containing $56.6 \%$ protein, $14.6 \%$ fat and $8.9 \%$ ash (Hughes \& Rumsey 1991). The feed pellet size was adjusted to the mouth orifice of the different-sized fish. the feeding rate was set at $10 \%$ of the average body weight per day for the cichlid fish and 5\% per day for the hybrid striped bass. The food was administered twice a day (early morning and late afternoon) for 5 days, and once a day during the remaining 2 days of the week. Food ration was altered every fortnight based on the estimated growth rate of fish this size.

During feeding sessions fish were observed from a distance in order to see whether the addition of MA to the diet had affected their feeding behaviour and food consumption.

In the experimental groups receiving MA augmentation, the MA was evenly sprayed on the pellets and allowed to dry overnight before being used. A new batch was prepared biweekly to prevent degradation in MA levels. Food was stored in sealed plastic containers in a freezer $\left(-20^{\circ} \mathrm{C}\right)$, and the daily ration was removed from the freezer and left to thaw fully before feeding the fish.

\section{Water quality and fish sampling}

The following conditions prevailed throughout the experimental rearing period: dissolved oxygen, monitored with the aid of a YSI (Yellow Springs Instruments, Yellow Springs, OH, USA) oxygen meter, fluctuated between 5.3 and $7.2 \mathrm{mgL}^{-1}$; the photoperiod was maintained at 12L:12D with artificial fluorescent illumination; water $\mathrm{pH}$ values ranged from 6.6 to 7.2; and measurements of nitrogenous products were performed three times a week using Aquamerck (Merck, Damstadt, Germany) kits. In the hybrid striped bass flowthrough system, the ammonia $\left(\mathrm{NH}_{4}^{+}\right)$levels were found to be $0.05-0.1 \mathrm{mg} \mathrm{L}^{-1}$, while nitrite- $\mathrm{N}=0.01-$ $0.03 \mathrm{mg} \mathrm{L}^{-1}$, and nitrate- $\mathrm{N}=1.0-10 \mathrm{mg} \mathrm{L}^{-1}$. In the ornamental fish aquaria the ammonia $\left(\mathrm{NH}_{4}^{+}\right)$levels were found to be higher, ranging from 0.1 to $0.5 \mathrm{mg} \mathrm{L}^{-1}$, while nitrite-N ranged from 0.1 to $1.0 \mathrm{mg} \mathrm{L}^{-1}$.

At the end of the 6-week growth period, the fish were food deprived for 1 day and a sample of fish from each tank was removed. The fish were decapitated, their digestive tracts were dissected and the different tissues were placed in test tubes to which approximately $2 \mathrm{~mL}$ solution of $0.1 \%$ sodium azide $\left(\mathrm{NaN}_{3}\right)$ was added to prevent microbial degradation. The following fish body parts were sampled: scales and outer surface mucus, liver, spleen, fat bodies and the muscle near the dorsal fin. Samples were then sealed and kept frozen at $-20{ }^{\circ} \mathrm{C}$ until analysis.

In a second experiment, the experimental procedure was repeated using juvenile African cichlid fish A. jacobfreibergi each weighing approximately $1 \mathrm{~g}$, and fed the same feed adulterated with $1000 \mathrm{mg} \mathrm{kg}^{-1}$ MA. Administration of food and weighing regime were the same as in the hybrid striped bass experiment.

\section{Chemicals and solvents}

Methyl anthranilate was purchased from Fluka Chemical Company (Bucks, Switzerland). All solvents were of high-performance liquid chromatography (HPLC) grade and were used without additional purification.

\section{Tissue analysis}

Instrumentation

A SpeedVac Savant Concentrator, a 220 ultrasonic bath and an EIC HN-S II centrifuge (Bransonic, Emerson, St Louis, MO, USA) were used for extraction of tissue and food samples. HPLC was performed using a Raining HPXL two-pump solvent delivery system, Rheodyne (Rohnert Park, CA, USA) 7161 sample injector equipped with a $20 \mu \mathrm{L}$ sample loop. The detection was carried out by a Dynamax (Houston, TX, USA) FL-1 fluorescent detector. Chromatorgams were recorded and integrated using a Hewlett Packard (Palo Alto, CA, USA) 3390A integrator.

Test tubes containing the fish tissue were thawed, and the tissue was mechanically crushed with the aid of glass rods. A mixture of methanol:chloroform (2:1) was added to each test tube, which was then placed in a sonicator for $1.5 \mathrm{~h}$ to ensure that as much MA as possible could be extracted from the shredded tissue.

\section{Extraction procedure 1}

A weighed sample of tissue (approximately 1g) was homogenized in $5 \mathrm{~mL}$ of chloroform: methanol (2:1) mixture and the mixture was ultrasonicated for $4 \mathrm{~h}$ 
at ambient temperature. The extract was separated by centrifugation, the solid residue after centrifugation was washed with $4 \mathrm{~mL}$ of chloroform-methanol (2:1) mixture and the solution obtained was added to the extract. The combined extract was evaporated to dryness and re-dissolved in the volume of isopropanol necessary to provide $2 \mathrm{~mL}$ of total volume. Aliquots of the isopropanol solution were analysed by HPLC.

\section{Extraction procedure 2}

This procedure was utilized for smaller samples to be analysed. They were homogenized, and the homogenate was lyophilized. The dry material obtained was extracted as described above.

High-performance liquid chromatography (HPLC) analysis was carried out on a silica gel (Zorbax Sil, Bodman Industries, Aston, PA, USA) $4.6 \times 250 \mathrm{~mm}$ column in hexane $t$-butylmethyl ether (95:5) at a flow rate of $3 \mathrm{~mL} \mathrm{~min}^{-1}$. Methyl anthranilate in the outcoming solution was detected by fluorescence, with excitation and emission wavelengths set up at 330 and $416 \mathrm{~nm}$ respectively. A solution of $1 \mu \mathrm{g} \mathrm{g}^{-1}$ of MA in isopropanol was used as an external standard. The retention time was around $4 \frac{1}{2} \mathrm{~min}$. The limits of MA quantification and detection were around $0.005 \mu \mathrm{g} \mathrm{g}^{-1}$, similar to the results of the method for MA quantification used by Thompson and Quaife (2001).

\section{Statistical analysis}

The results were subjected to ANOVA followed by Tukey's pair test.

\section{Results}

\section{Fish growth and survival}

The fish growth results are presented in Table 1. The growth and survival rates over the entire experimental period were the same, with no significant differences for both fish fed either the control food or the MA-treated food. The overall survival of the African cichlid fish was lower (probably because of their vulnerability at the small initial size at which they were stocked). Observations carried out during the fish feeding showed that the fish were not repelled by the presence of MA, and the food consumption rate was the same for both control and MA-treated food in both the species tested, and all given food was consumed by the end of the feeding session.

\section{MA bioaccumulation in fish}

The results of the bioaccumulation and MA presence tests are presented in Table 2. Bioaccumulation of MA was significantly higher in the fish consuming food adulterated with MA, and the highest levels were found in the lipholitic organs of the body. Yet, low levels of MA (around $0.6 \mu \mathrm{gg}^{-1}$ ) were found even in the control fish consuming food that had no MA added to it. Hybrid striped bass fed the MA-treated feed, to which $100 \mathrm{mg} \mathrm{kg}^{-1}$ of MA had been added, were found to contain only $11.2 \mu \mathrm{gg}^{-1}$ of MA in the abdominal fat. Following the 6 -week depuration period of these fish, the levels of MA found in the fish dropped considerably and were only around $10 \%$ of the level found at the end of the 6 -week period during which the fish received food containing MA (see

Table 1 Growth and survival of juvenile fish reared for 6 weeks on a diet adulterated with methyl anthranilate (MA)

\begin{tabular}{|c|c|c|c|}
\hline Hybrid striped bass & Initial weight (g) & Final weight (g) & Survival (\%) \\
\hline Fish fed a diet with $100 \mathrm{mg} \mathrm{kg}^{-1} \mathrm{MA}$ added & $10.76 \pm 1.89^{a}$ & $19.34 \pm 3.58^{\mathrm{a}}$ & $95.48 \pm 4.5^{\mathrm{a}}$ \\
\hline Fish fed the same diet with no MA added & $10.58 \pm 1.72^{\mathrm{a}}$ & $18.93 \pm 3.74^{\mathrm{a}}$ & $96.96 \pm 2.63^{\mathrm{a}}$ \\
\hline Following a 6-week depuration & $19.34 \pm 3.58$ & $32.64 \pm 4.83$ & 100 \\
\hline \multicolumn{4}{|l|}{ African cichlid fish Aulonocara jacobfreibergi } \\
\hline Fish fed a diet with $1000 \mathrm{mg} \mathrm{kg}^{-1} \mathrm{MA}$ added & $0.91 \pm 0.12^{\mathrm{a}}$ & $2.42 \pm 0.68^{\mathrm{a}}$ & $72.22 \pm 21.26^{\mathrm{a}}$ \\
\hline Fish fed the same diet with no MA added & $0.96 \pm 0.09^{\mathrm{a}}$ & $2.58 \pm 0.72^{\mathrm{a}}$ & $74.44 \pm 22.87^{\mathrm{a}}$ \\
\hline
\end{tabular}

Hybrid striped bass fish were fed a feed adulterated with $100 \mathrm{mg} \mathrm{kg}^{-1}$ and juvenile African cichlid fish A. jacobfreibergi were fed a feed adulterated with $1000 \mathrm{mg} \mathrm{kg}^{-1}$.

Concentrations presented are in $\mu \mathrm{gg}^{-1}$ units \pm SD.

Values in the same column followed by the same superscript are not significantly different $(P<0.01 ; N=3$ for hybrid striped bass; $N=6$ for African cichlid).

Concentration of MA found in the food was $2.6 \pm 1.9 \mu \mathrm{gg}^{-1}$ in the control diet and $110.2 \pm 16.7$ and $976.8 \pm 78.7 \mu \mathrm{gg}{ }^{-1}$ for the 100 and $1000 \mathrm{mg} \mathrm{kg}^{-1}$ addition of MA diets respectively. 
Table 2 Bioaccumulation of methyl anthranilate (MA) in different body parts of hybrid striped bass juvenile fish fed feed adulterated with $100 \mathrm{mg} \mathrm{kg}^{-1}$ for 6 weeks

\begin{tabular}{|c|c|c|c|c|c|}
\hline Hybrid striped bass & Spleen & Liver & Abdominal fat & Muscle & $\begin{array}{l}\text { Scales } \\
\text { and mucus }\end{array}$ \\
\hline Fish fed a diet with $100 \mathrm{mg} \mathrm{kg}^{-1} \mathrm{MA}$ added & $6.7 \pm 1.8^{\mathrm{a}}$ & $8.9 \pm 2.1^{a}$ & $11.2 \pm 2.6^{\mathrm{a}}$ & $0.1 \pm 0.05^{\mathrm{b}}$ & Traces \\
\hline Fish fed the same diet with no MA added & $0.5 \pm 0.2^{\mathrm{a}}$ & $0.3 \pm 0.2^{\mathrm{a}}$ & $0.6 \pm 0.3^{\mathrm{a}}$ & $0.05 \pm 0.04^{b}$ & 0 \\
\hline $\begin{array}{l}\text { Following a } 6 \text {-week depuration period in } \\
\text { which no MA was added }\end{array}$ & $0.6 \pm 0.3^{a}$ & $0.9 \pm 0.4^{a}$ & $1.3 \pm 0.3^{a}$ & 0 & 0 \\
\hline
\end{tabular}

Concentrations presented are in $\mu \mathrm{gg}^{-1}$ units \pm SD.

Values in the same row followed by the same superscript are not significantly different $(P<0.01 ; N=12)$.

Concentrations of MA found in the control food was $2.6 \pm 1.9 \mu \mathrm{gg}^{-1}$, while the food that had MA added to it was found to have $110.2 \pm 16.7 \mu \mathrm{g} \mathrm{g}^{-1}$.

Table 2). This level was still above the levels found in the corresponding control fish that received no addition of MA to their diet.

The concentration of MA in the whole body of juvenile African cichlid fish A. jacobfreibergi fed feed adulterated with $1000 \mathrm{mg} \mathrm{kg}^{-1} \mathrm{MA}$ for 6 weeks was found to be $12.7 \pm 2.1 \mu \mathrm{g} \mathrm{g}^{-1}$. This corresponds to a deposition rate (whole-body accumulation/food intake level) of roughly $0.3 \%$, while the deposition rate in the hybrid striped bass fed feed adulterated with $100 \mathrm{mg} \mathrm{kg}^{-1} \mathrm{MA}$ corresponded to $0.7 \%$.

\section{Discussion}

The presence of MA in the fish diet of $100 \mathrm{mg} \mathrm{kg}^{-1}$ and even at a higher level of $1000 \mathrm{mg} \mathrm{kg}^{-1}$ did not affect the growth or the survival of fish over a period of 6 weeks. No long-term detrimental effects were found in fish that were fed $100 \mathrm{mg} \mathrm{kg}^{-1} \mathrm{MA}$ for a period of 6 weeks and then switched to a diet containing no MA for an additional 6 weeks. It therefore seems that MA can be safely used as an additive to the diets of juvenile hybrid striped bass and ornamental cichlid fish, to act as a bird repellent, preventing birds from consuming the fish food during storage as well as when the food is floating in the water before its consumption by the fish. This has growing importance since some birds learn to feed on the pellets used as fish feed. This has become especially problematic with the increasing use of floating pellets by the industry. The chemical structure of MA (methyl 2-aminobenzoate) is very similar to a widely used fish anaesthetic,ethyl $m$-aminobenzoate, also known as MS222. A relatively low concentration of MA in the rearing water will therefore have an anaesthetic effect on the fish and might lead to fish mortality. It is therefore not surprising that when the effects of MA were tested in small stagnant water aquariums with the fry of four species of fish, it was found that the $\mathrm{LC}_{50}$ at $24 \mathrm{~h}$ for Atlantic salmon (Salmo salar L.), rainbow trout (Oncorhynus mykiss Richardson), channel catfish (Ictalurus punctatus Raf.) and bluegill sunfish (Lepomis macrochirus Raf.) was between 20 and $32.3 \mathrm{mg} \mathrm{L}^{-1}$ (Clark et al. 1993). Yet, even at a concentration of $1000 \mathrm{mg} \mathrm{MA} \mathrm{kg}^{-1}$ feed, we observed no toxic effect on the African cichlid's feeding behaviour or survival. At the level the fish were fed $(10 \%$ of their body weight day ${ }^{-1}$ ), the amount of MA added to the $35 \mathrm{~L}$ aquarium was $2-6 \mathrm{mg}$ day $^{-1}$. Therefore, even if the MA quantity delivered over the entire experiment did not degrade (or accumulate in the fish), the levels present would not pose a threat to the well-being of the fish.

The presence of MA in the outer mucus of the fish may be advantageous as this is the part that fish-eating birds first come in contact with, and it may deter them from consuming the fish. Unfortunately, we found no presence of MA in the outer mucus of the fish.

Following the 6-week depuration period for hybrid striped bass juveniles, the levels of MA detected in the fish dropped considerably and were only around $10 \%$ of the level found at the onset of the depuration period (see Table 2). During the depuration period, the weight of the fish had doubled. Therefore, because of the effect of dilution, one would expect a $50 \%$ reduction in the level of MA in the fish. Although the MA level detected in these fish is higher than the level found in the control fish, it is lower than the level expected and shows that MA wash out did indeed occur. The overall growth rate of the hybrid striped bass (in both the control and MA-fed fish) was lower than that observed in earthen ponds, and can be attributed to 
the lower temperature at which they were kept, the period it took for them to become accustomed to the artificial feed used and the lack of natural food available in outdoor ponds.

The typical levels of MA found in human food items such as ice cream and baked goods are around $20 \mu \mathrm{g} \mathrm{g}^{-1}$, while in grape-flavoured chewing gum the reported level is above $2000 \mu^{g^{-1}}$ (Furia \& Bellanca 1975). Therefore, the levels detected in the MAtreated fish are around and below those of other food items. Furthermore, taking into account the fact that the fish body parts containing the highest levels of MA (liver and abdominal fat bodies) are usually discarded, we conclude that the addition of MA to the fish food does not pose a problem for consumers of hybrid striped fish fed diets containing MA.

A study conducted on captive double-crested cormorant Phalacrocorax auritus predation on channel catfish I. punctatus fingerlings showed that their predation can strongly influence the final yield of fish when they are reared in a single-batch crop, the damage amounting to about one-third of the fish and about one-quarter of the biomass lost (Glahn \& Dorr 2002). Thus, it is very important to use a repellent to minimize bird presence in the vulnerable juvenile stage of fish growth.

Experiments conducted on catfish farms in southern USA, in which MA was used as a bird repellent, did not show that fish predation level was reduced when this chemical was applied (Dorr, Clark, Glahn \& Mezine 1998). Yet, observations conducted in Israel (D. Shelach, pers. comm.) show that herons and cormorants were deterred from fish ponds in which MA was applied by spreading it around the circumference of 1 ha ponds. This resulted in a considerable reduction in juvenile fish losses. In addition to repelling fish-eating birds from the pond area, the use of the repellent protected the floating pellets used in the pond from being consumed by ducks and a number of other bird species present in the pond area. Application of MA to the fish food pellets may be a method to deter birds not only from the pellets but from the ponds as well but this remains to be evaluated.

\section{Acknowledgments}

This study was carried out at the Monell Chemical Senses Center, Philadelphia, PA, USA and the authors wish to thank the Center for providing space and assistance for carrying out the research work. The superb technical assistance of the late Eugeny Aronov is greatly appreciated.

\section{References}

Avery M.L. (2002) Behavioral and ecological considerations of managing bird damage to cultivated fruit. In: Seed Dispersal and Frugivory: Ecology, Evolution and Conservation (ed. by D.J. Levy, W.R. Silva \& M. Galetti), pp. 467-477. CAB International, Oxon, UK.

Avery M.L., Eiselman D.S., Young M.K., Humphrey J.S. \& Decker D.G. (1999) Wading bird predation at tropical aquaculture facilities in central Florida. North American Journal of Aquaculture 61, 64-69.

Belant J.L., Tyson L.A. \& Mastrangelo P.A. (2000) Effects of lethal control at aquaculture facilities on populations of piscivorous birds. Wildlife Society Bulletin 28, 379-384.

Blackwell B.F., Dolbeer R.A. \& Tyson L.A. (2000) Lethal control of piscivorous birds at aquaculture facilities in the northeast United States: effects on populations. North American Journal of Aquaculture 62, 300-307.

Clark L. \& Shah P.S. (1993) Chemical bird repellents: possible use in cyanide ponds. Journal of Wildlife Management 57, 657-664.

Clark L., Shah P.S. \& Mason J.R. (1991) Chemical repellency in birds: relationship between chemical structure and avoidance response. Journal of Experimental Zoology $\mathbf{2 6 0}$, 310-322.

Clark L., Cummings J., Bird S. \& Aronov E. (1993) Acute toxicity of the bird repellent, methyl anthranilate, to fry of Salmo salar, Oncorhynus mykiss, Ictalurus punctatus and Lepomis macrochirus. Pesticide Science 39, 313-317.

Dolbeer R.A., Woronecki P.P., Stearns T.W. \& Clark L. (1992) Pen tests of methyl anthranilate as a bird repellent in water. Proceedings of Fifth East Wildlife Damage Control Conference 5, 112-116.

Dorr B., Clark L., Glahn J.F. \& Mezine I. (1998) Evaluation of a methyl anthranilate-based bird repellent: toxicity to channel catfish Ictalurus punctatus and effect on great blue heron Ardea herodias feeding behaviour. Journal of World Aquatic Society 29, 451-462.

Fleury B.E. \& Sherry T.W. (1995) Long-term population trends of colonial wading birds in the southern United States: the impact of crayfish aquaculture on Louisiana populations. Auk 112, 613-632.

Furia T.E. \& Bellanca N. (1975) In: Handbook of Flavor Ingredients, Vol. 2, (ed. by S. Fenaroli), p. 346. CRC Press, Cleveland, $\mathrm{OH}$.

Glahn J.F. \& Brugger K.E. (1995) The impact of double-crested cormorants on the Mississippi Delta catfish industry: a bioenergetics model. Colonial Waterbirds 18, 168-175.

Glahn J.F. \& Dorr B. (2002) Captive double crested cormorant Phalacrocorax auritus predation on channel catfish Ictalurus punctatus fingerlings and its influence on singlebatch cropping production. Journal World Aquaculture Society 33, 85-93.

Glahn J.F., Mason J.R. \& Woods D.R. (1989) Dimethyl anthranilate as a bird repellent in livestock feed. Wildlife Society Bulletin 17, 313-320. 
Glahn J.F., Rasmussen E.S., Tomsa T. \& Preusser K.J. (1999) Distribution and relative impact of avian predators at aquaculture facilities in the northeastern United States. North American Journal of Aquaculture 61, 340-348.

Glahn J.F., Tomsa T. \& Preusser K.J. (1999) Impact of great blue heron predation at trout-rearing facilities in the northeastern United States. North American Journal of Aquaculture 61, 349-354.

Glahn J.F., Dorr B. \& Tobin M.E. (2000) Captive Great Blue Heron predation on farmed Channel catfish fingerlings. North American Journal of Aquaculture 62, 149-156.

Glahn J.F., Werner S.J., Hanson T. \& Engle C.R. (2000) Cormorant depredation losses and their prevention at catfish farms: economic considerations. In: Human Conflicts with Wildlife: Economic Considerations. Proceedings of the 3rd NWRC Special Symposium, 1-3 August 2000 (ed. by L. Clark), pp. 138-146. National Wildlife Research Center, Fort Collins, CO, USA.

Hughes S.G. \& Rumsey G.L. (1991) Starter salmon feeds: new concepts in protein supplementation. Feed Management 42, 58-62.

James D.G. (2005) Further field evaluation of synthetic herbivore-induced plant volatiles as attractants for beneficial insects. Journal Chemical Ecology 31, 481-495.

Mason J.R, Glahn J.F., Dolbeer R.A. \& Reidinger R.F. (1985) Field evaluation of dimethyl anthranilate as a bird repellent livestock feed additive. Journal Wildlife Management 49, 636-642.
Mason J.R., Adams M.J. \& Clark L. (1989) Anthranilate repellency to starlings: hemical correlates and sensory perception. Journal Wildlife Management 53, 55-64.

Mason J.R., Clark L. \& Miller T.P. (1993) Evaluation of a pelleted bait containing methyl anthranilate as a bird repellent. Pesticide Science 39, 299-304.

Melotti P., Loro F., Roncarati A. \& Impiccini R. (1994) Predation of sea bass (Dicentrarchus labrax L.) in the second year of intensive farming by fish-eating birds. Riv Ital Acqaucolt 29, 23-30.

Mott D.F. \& Boyd F.L. (1995) A review of techniques for preventing cormorant depredations at aquaculture facilities in the southeastern United States. Colonial Waterbirds 18 , 176-180.

Price I.M. \& Nickum J.G. (1995) Aquaculture and birds: the context for controversy. Colonial Waterbirds 18, $33-45$.

Russell I.C., Dare P.J., Eaton D.R. \& Armstrong J.D. (1996) Assessment of the Problem of Fish-Eating Birds in Inland Fisheries in England and Wales. Directorate of Fisheries Research, Lowestoft, UK, 130pp.

Thompson R.D. \& Quaife J.T. (2001) Liquid chromatographic determination of methyl anthranilate in artificially flavored nonalcoholic beverages. Journal of AOAC International 84, 493-497.

Ulenaers P. \& Van Vessem J. (1994) Impact of great crested grebes (Podiceps cristatus L) on fish ponds. Hydrobiologia 280, 353-366. 